\title{
The dependence of long-distance migration to North Norway on environmental conditions in the wintering area and en route
}

\author{
Robert T. Barrett
}

Department of Natural Sciences, Tromsø University Museum, PO Box 6050 Langnes, NO-9037 Tromsø, Norway; e-mail: rob.barrett@uit.no

\begin{abstract}
The onset of bird migration may be under partial endogenous control whereas the timing of movement is flexible with weather and conditions faced by the moving birds being the ultimate cause of variability of arrival dates. This study shows that the early arrival dates of two of three long-distance passerine spring migrants (Willow Warblers Phylloscopus trochilus and Chiffchaffs $P$. collybita) in North Norway were unrelated to climatic conditions at the start of their migration in Africa and en route through Europe until they reached Scandinavia. Although climate in W Africa may have affected departure dates, the timing of arrival of the first Pied Flycatchers Ficedula hypoleuca seemed to be unrelated to conditions along the whole route, including the target area.
\end{abstract}

Key words: migration, early arrival date, phenology, climate impacts, North Norway

\section{INTRODUCTION}

There has been much focus on the phenological effects of climate change on ecosystems in recent years. Birds in particular have responded to warming trends with a general advance of spring migration and earlier arrival dates of birds in northern latitudes (e.g. Lehikoinen et al. 2006, Lehikoinen \& Sparks 2010, Usui et al. 2017). The arrival date of a migrant is a function of the date of departure from the winter grounds, the speed of flight and the time spent at stopovers (Lehikoinen et al. 2006, Gordo 2007). Although the onset of migration may be under partial endogenous control (Gwinner 1996), the timing is flexible with weather and conditions faced by the moving birds being the ultimate cause of variability of arrival dates. Thus weather experienced en route and in the goal area may be important in determining arrival dates (Ahola et al. 2004, Marra et al. 2005, Hüppop \& Winkel 2006, Tøttrup et al. 2008). In North Norway, many species have started to arrive earlier since the mid-1990s (Barrett 2011). Although their arrival dates were shown to be advanced in warm years, there was no evidence of a rise in spring temperature in the region during the study period $(1980-2010)$ that could explain the change in migration phenology (Barrett 2011). It was instead suggested that they were responding more to environmental conditions experienced en route during migration northwards than in the breeding grounds. Further south in Europe, arrival times of e.g. trans-Saharan migrants have also been shown to vary in response to departure dates from wintering areas that, in turn, were associated with variations in thermal conditions and rainfall anomalies in and south of the Sahel region in West Africa (Saino et al. 2007, Ouwehand \& Both 2017). The responses of these species may, however, vary in both space and time (Tøttrup et al. 2008, Jenouvrier 2013) and how environmental conditions affect southern populations may not apply to those from the far north (Gordo 2007).

With this in mind and with six more years of data since the last study (Barrett 2011), the migration phenologies of three long-distance insectivore migrants were revisited. Two were trans-Saharan migrants, the Pied Flycatcher Ficedula hypoleuca and the Willow Warbler Phylloscopus trochilus that are widespread as breeding birds in North Norway and spend the winter south of the Sahara in Africa. Norwegian Pied Flycatchers have been shown to winter mainly in West Africa north of the Gulf of Guinea whereas Willow Warblers from northern Scandinavia tend to winter further east in central, eastern and southern parts of Africa (Hedenström \& Pettersson 1987, Bakken et al. 2006, Ouwehand et al. 2016, Thingstad et al. 2015). As such, Pied Flycatchers have a more westerly migration route through NW Africa and the Iberian Peninsula than Willow Warblers that move northwards through the eastern Mediterranean and presumably the Balkans (Hedenström \& Pettersson 1987) (Figure 1). The third was the Chiffchaff Phylloscopus collybita that winters in North Africa and around the western Mediterranean and is thought to use the westerly return route through Iberia (Catry et al. 2005, Bakken et al. 2006).

Arrival times may be affected in two ways, either prior to departure when changeable environmental conditions can affect food supply and hence body condition, or en route when conditions may favour or 


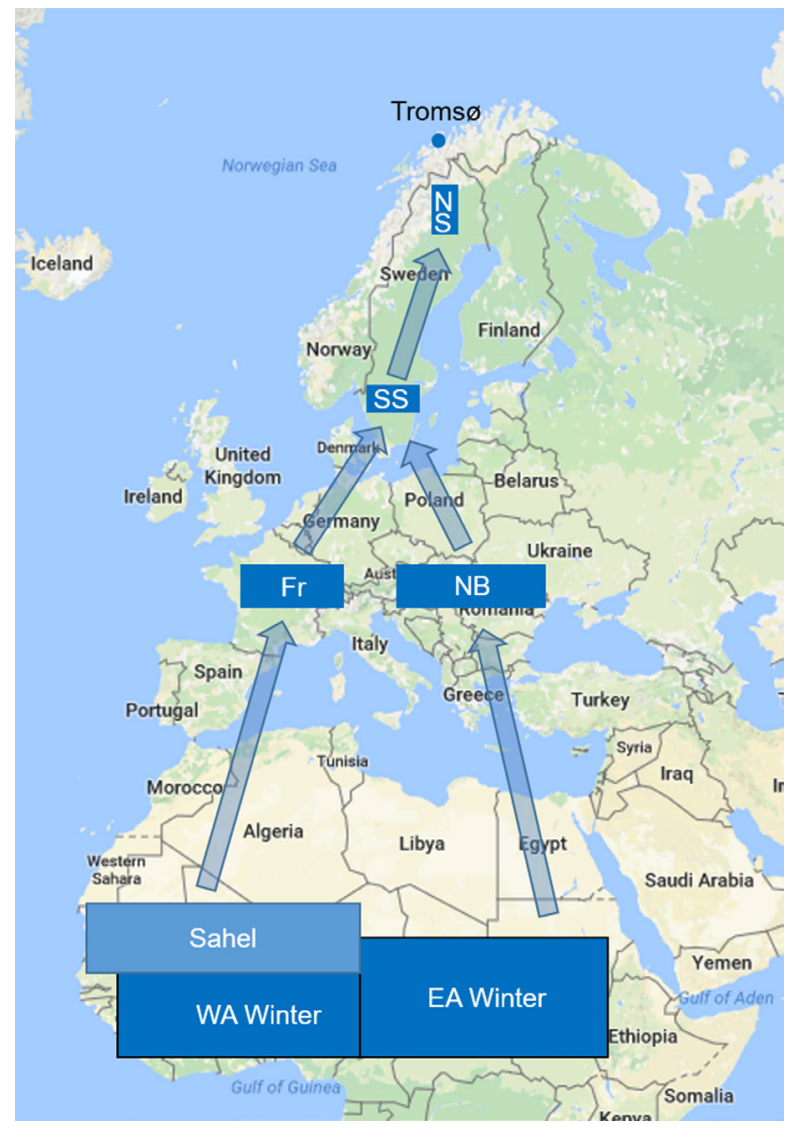

Figure 1. Approximate positions of areas for which climate data were downloaded along the migration route of Pied Flycatchers, Willow Warblers and Chiffchaffs between the wintering area and breeding area in North Norway (WA = West Africa, EA $=$ East Africa, Fr $=$ France, $\mathrm{NB}=$ Northern Balkans, SS =South Sweden and NS $=$ North Sweden - see Appendix 1 for geographical coordinates of the areas). The western (Pied Flycatchers, Chiffchaffs) and eastern (Willow Warblers) return routes are indicated by arrows.

delay refuelling (Ahola et al. 2004, Gordo et al. 2005). Here, I relate arrival times of the three spring migrants to climatic conditions at the start of their northward migration and en route to North Norway to see where the responses are strongest.

\section{METHODS}

A database of spring arrival dates of the first individuals and small flocks of nearly 100 species as reported directly to me and on-line by birdwatchers, members of the public and members of the regional branch of the Norwegian Ornithological Society has been built up since the early 1970s (Barrett 2002). This analysis is based on data collected in and since 1980 by which time reports were arriving in a more systematic manner. Although data exist for every year, this study was restricted to years for which there was a minimum observation set of four dates in four different localities in any one year. To reduce the possibility of including overwintering birds or extreme early arrivals of outlying "rogue" individuals (Sparks et al. 2001), analyses were based on the second and third observation dates of individual(s) in the county. The three chosen species are all common in Troms, easily recognized (partly through their song) and breed in or near human settlements thus increasing the chances of detection on arrival and hence the robustness of the data collected (Tryjanowski et al. 2005).

Time trends were first sought using a simple linear regression analysis of arrival date in Troms against year. Because an earlier study in Troms (Barrett 2011) had found non-linear relationships with an early period of no apparent trends followed by an advancement of arrival dates in 29 of 42 species, a segmented piecewise regression analysis was then applied to the data sets.

An overview of covariates used in the regression models examining the variation in arrival dates of migrants is given in Appendix 1. The large-scale North Atlantic Oscillation (NAO) index is a good summary of weather conditions over Europe that are important drivers of ecosystem functioning with high winter indices associated with early spring, including insect emergence (Forchhammer et al. 2002, Sokolov \& Kosarev 2003, Gordo 2007). As a proxy of the habitat quality in the wintering area of Pied Flycatchers in West Africa (Ouwehand \& Both 2016), the wet season rainfall index was chosen. Positive index values indicate a higher precipitation than the long-term mean, and

Table 1. Time trend analyses (linear and segmented piecewise regression, based on $2^{\text {nd }}$ and $3^{\text {rd }}$ observations) of arrival dates of Chiffchaffs, Willow Warblers and Pied Flycatchers to Troms, North Norway between 1980 and 2016.

\begin{tabular}{|c|c|c|c|c|c|c|c|}
\hline & \multicolumn{3}{|c|}{ Linear regression } & \multicolumn{4}{|c|}{ Segmented piecewise regression } \\
\hline & Slope & $r^{2}$ & $\mathrm{p}$ & Break & $r^{2}$ & $\mathrm{p}$ & $\mathrm{df}$ \\
\hline Chiffchaff $2^{\text {nd }}$ obs. & -0.48 & 0.377 & $<0.001$ & 1995 & 0.400 & $<0.001$ & 31 \\
\hline Willow Warbler $2^{\text {nd }}$ obs. & -0.35 & 0.354 & $<0.001$ & 1995 & 0.334 & $<0.001$ & 35 \\
\hline Pied Flycatcher $2^{\text {nd }}$ obs. & -0.26 & 0.324 & $<0.001$ & & & & \\
\hline Chiffchaff $3^{\text {rd }}$ obs. & -0.49 & 0.382 & $<0.001$ & 1995 & 0.401 & $<0.001$ & 31 \\
\hline Willow Warbler $3^{\text {rd }}$ obs. & -0.36 & 0.311 & $<0.001$ & 1996 & 0.324 & $<0.001$ & 35 \\
\hline Pied Flycatcher $3^{\text {rd }}$ obs. & -0.27 & 0.368 & $<0.001$ & & & & \\
\hline
\end{tabular}


negative a lower precipitation. A second representation of the departure conditions of Pied Flycatchers was the mean of the monthly Sahel precipitation indices for March and April. For the Pied Flycatcher and Willow Warbler, the proxy of departure conditions were the mean March-April temperature anomalies in the wintering area (Appendix 1, Figure 1). This assumed that the birds left their winter quarters during the second half of March-early April as documented for West European-breeding Pied Flycatchers (Ouwehand et al. 2016, Ouwehand \& Both 2017). A third proxy of conditions at departure and one en route was again the winter North Atlantic Oscillation Index. A high index gives rise to warmer, wetter and windier conditions that improve foraging conditions in both Africa and Europe and thus allow earlier departure and/or a more rapid movement northwards (Hüppop \& Hüppop 2003, Cotton 2003).

Representations of conditions along the migration route northwards were monthly temperature anomalies in France (for Pied Flycatchers and Chiffchaffs) and in the northern Balkans (for Willow Warblers) in April and absolute measurements of temperature in South and North Sweden. Proxies of conditions on arrival in Troms were the annual means of daily mean temperatures between 16 April and 15 May recorded at Tromsø Meteorological Station (Figure 1). All time periods for explanatory climate factors were aimed to coincide with the known migration phenology of the three species studied. As a control, regressions were also carried out using means of temperatures (anomalies and absolute values) and precipitation anomalies for the relevant single months (March, April or May).

Regression analyses were carried out using Minitab 17 statistical software and segmented piecewise regression analyses were applied using an interactive method downloaded from an earlier Excel Resources web page (based on Ryan \& Porth 2007). Initial inspection of many of the time series showed clear time trends (Figure 2, Appendix 2) and to avoid risks of autocorrelation, regressions were based on the residuals of trend analyses of all time series.

\section{RESULTS}

There was considerable variation in the arrival dates of the three passerine species from year to year. The Chiffchaff arrived in Troms first, in late April/early May with second observation dates spanning 1 month (11 April - 11 May) and Pied Flycatchers and Willow Warblers arrivals were ca. $10 \mathrm{~d}$ later and spanned 3 weeks (28 April - 21 May) (Figure 2, Appendix 3). All three species tended to advance their arrival during the period of study (Figure 2, Table 1) but segmented regression analyses revealed changes in the advance for Chiffchaffs and Willow Warblers did not start until
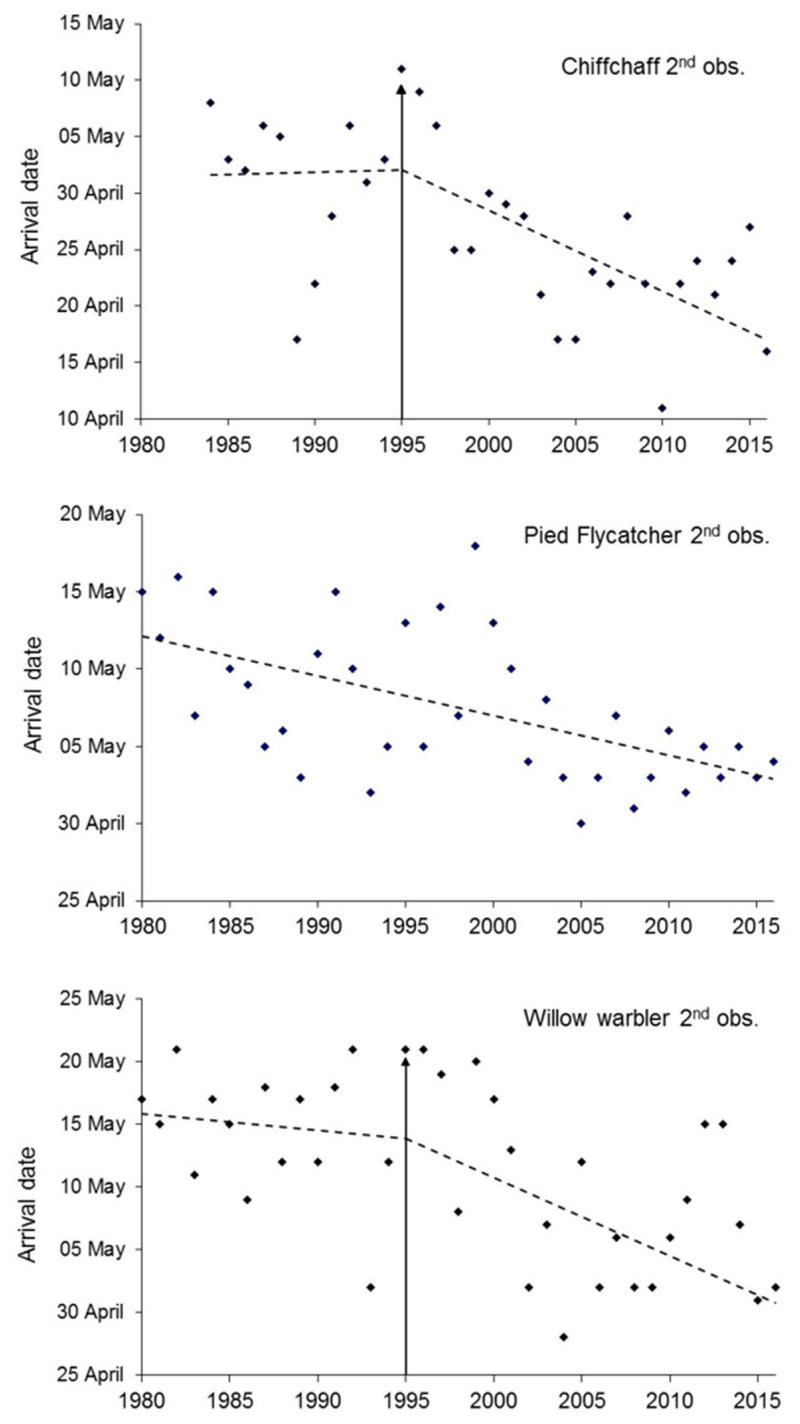

Figure 2. Observed dates of arrival ( $2^{\text {nd }}$ observations) of spring-migrating Chiffchaffs, Pied Flycatchers and Willow Warblers at Troms, North Norway. Dotted lines are regression lines and arrows mark the break points of segmented piecewise regressions. Regression statistics are given in Tables $1 \& 2$.

the mid-1990s (Table 1, Figure 2). While the arrival of Pied Flycatchers advanced at a rate of $0.25 \mathrm{~d} \mathrm{yr}^{-1}$ throughout the study period $(1980-2016)$, there was no change among Chiffchaffs until 1995, after which they advanced their arrival by $0.7 \mathrm{~d} \mathrm{yr}^{-1}$. Willow Warblers also started their advance in 1995 at a rate of $0.5-0.6 \mathrm{~d}$ $\mathrm{yr}^{-1}$ (Table 2).

There was no relationship between variations in the NAO winter index and arrival dates of any of the species studied (Table 3). Temperatures and precipitation in West Africa were, however, related to the arrival times of the Pied Flycatcher in North Norway with more rain and lower temperatures in April resulting in a delay in arrival (Table 3). As the birds migrated northwards, however, the only relationship between arrival dates in Troms and temperatures en 
Table 2. Time trend analyses of arrival dates before and after the piecewise regression breakpoints for Chiffchaffs and Willow Warblers to Troms, North Norway between 1980 and 2016, based on $2^{\text {nd }}$ and $3^{\text {rd }}$ observations.

\begin{tabular}{|c|c|c|c|c|c|c|c|c|c|}
\hline & \multicolumn{5}{|c|}{ Before break } & \multicolumn{4}{|c|}{ After break } \\
\hline & Break & Slope & $\mathrm{r}^{2}$ & $\mathrm{p}$ & $\mathrm{df}$ & Slope & $\mathrm{r}^{2}$ & $\mathrm{p}$ & $\mathrm{df}$ \\
\hline Chiffchaff $2^{\text {nd }}$ obs. & 1995 & 0.04 & $<0.001$ & 0.954 & 10 & -0.72 & 0.409 & 0.001 & 20 \\
\hline Willow Warbler $2^{\text {nd }}$ obs. & 1995 & -0.13 & 0.015 & 0.654 & 14 & -0.62 & 0.306 & 0.007 & 20 \\
\hline Chiffchaff $3^{\text {rd }}$ obs. & 1995 & -0.03 & $<0.001$ & 0.966 & 10 & -0.71 & 0.419 & 0.001 & 20 \\
\hline Willow Warbler $3^{\text {rd }}$ obs. & 1996 & -0.14 & 0.016 & 0.633 & 15 & -0.53 & 0.237 & 0.025 & 19 \\
\hline
\end{tabular}

route were between arrivals of Willow Warblers and temperatures in both $\mathrm{S}$ and $\mathrm{N}$ Sweden (Table 3) with arrivals advancing in years of higher temperatures. The arrival dates of Pied Flycatchers, on the other hand, seemed to be independent of temperatures along the whole route, including their goal in Troms (Table 3). Like the Willow Warblers, Chiffchaffs advanced their arrival times in years of increased temperature in both $\mathrm{N}$ Sweden and in Troms (Table 3). Apart from the disclosure of April rain in Africa having an effect on arrival dates of flycatchers, the control tests using single month climate data did not alter any of the results.

\section{DISCUSSION}

At a global scale, birds have advanced their arrival date in response to increasing temperatures over many decades, with short-distance migrants advancing their timing significantly more than long-distance migrants

Table 3. Results of regression of arrival dates of the second and third individuals of Willow Warblers, Pied Flycatchers and Chiffchaffs in Troms on climate proxies in the wintering area (Winter NAO Index and E and W Africa monthly and bimonthly means of temperature and precipitation anomalies - TA \& PA) and en route (N Balkans or France, S and N Sweden) to their breeding area (Tromsø) between 1980 and 2016. (Numbers of years given in parentheses and significant relationships are shown in bold). See Appendix 1 for overview of climate proxies.

\begin{tabular}{|c|c|c|c|c|c|c|}
\hline & Slope & $\mathrm{r}^{2}$ & $\mathrm{p}$ & Slope & $\mathrm{r}^{2}$ & $\mathrm{p}$ \\
\hline & \multicolumn{3}{|c|}{ Pied Flycatcher $2^{\text {nd }}$ obs (36) } & \multicolumn{3}{|c|}{ Pied Flycatcher $3^{\text {rd }}$ obs $(36)$} \\
\hline NAOI (Dec.-March) & 0.06 & 0.0 & 0.926 & 0.18 & 0.30 & 0.752 \\
\hline Sahel wet season PA & $<0.01$ & 2.5 & 0.350 & $<0.01$ & 5.5 & 0.164 \\
\hline W Africa March/April PA & $<0.03$ & 7.7 & 0.086 & 0.02 & 4.8 & 0.191 \\
\hline W Africa April PA & 0.05 & 18.1 & 0.009 & 0.04 & 14.6 & 0.020 \\
\hline W Africa March/April TA & -2.63 & 7.6 & 0.099 & -3.06 & 11.2 & 0.043 \\
\hline France April TA & -0.21 & 0.4 & 0.707 & -0.19 & 0.4 & 0.718 \\
\hline S Sweden April/May temp. & -0.91 & 3.5 & 0.265 & -0.65 & 2.0 & 0.402 \\
\hline N Sweden Apr/May temp. & -0.61 & 3.7 & 0.252 & -0.40 & 1.8 & 0.432 \\
\hline \multirow[t]{2}{*}{ Tromsø Apr/May temp. } & -0.91 & 9.6 & 0.062 & -0.97 & 11.9 & 0.036 \\
\hline & \multicolumn{3}{|c|}{ W. Warbler $2^{\text {nd }}$ obs. (36) } & \multicolumn{3}{|c|}{ W. Warbler $3^{\text {rd }}$ obs. (36) } \\
\hline NAOI (Dec.-March) & -0.21 & 0.2 & 0.807 & -0.44 & 0.7 & 0.619 \\
\hline E Africa March/April TA & -0.25 & 0.0 & 0.914 & -0.39 & 0.1 & 0.867 \\
\hline N Balkans April TA & -0.82 & 3.1 & 0.294 & -1.06 & 5.1 & 0.178 \\
\hline S Sweden Apr/May temp. & -2.17 & 10.0 & 0.056 & -3.12 & 20.5 & 0.005 \\
\hline N Sweden Apr/May temp. & -1.85 & 16.8 & 0.012 & -2.35 & 27.3 & 0.001 \\
\hline \multirow[t]{2}{*}{ Tromsø Apr/May temp. } & -2.09 & 24.9 & 0.002 & -1.71 & 16.7 & 0.012 \\
\hline & \multicolumn{3}{|c|}{ Chiffchaff $2^{\text {nd }}$ obs. (32) } & \multicolumn{3}{|c|}{ Chiffchaff $3^{\text {rd }}$ obs. (32) } \\
\hline NAOI (Dec.-March) & 0.23 & 0.2 & 0.809 & -0.17 & 0.1 & 0.858 \\
\hline France April TA & 0.67 & 1.9 & 0.448 & 0.78 & 2.7 & 0.361 \\
\hline S Sweden Apr/May temp. & -1.82 & 6.5 & 0.151 & -2.10 & 9.0 & 0.089 \\
\hline N Sweden Apr/May temp. & -2.23 & 21.8 & 0.006 & -2.08 & 19.8 & 0.010 \\
\hline Tromsø Apr/May temp. & -2.46 & 29.2 & 0.001 & -2.46 & 29.2 & 0.001 \\
\hline
\end{tabular}


(Usui et al. 2016). The results of this study are thus expected, but unusual is the delay in the advance of two of the species (as also documented for 23 others in Barrett [2011]) until after the mid-1990s. In a review of 29 studies of arrival time in Europe, no mention is made of such a delay of advances recorded over the last half of the 20th century (Lehikoinen et al. 2006). Also in Cotton (2003), negative slopes of arrival dates plotted against year for 17 species in Oxfordshire, England were linear over the last three decades of the 20th century. That Chiffchaffs and Willow Warblers did not start their advance in arrival dates in Troms until the mid-1990s corroborates the results of the earlier study from the region and has been suggested to be due to a lack of advance in of the onset of the growing season (Barrett 2011). A piecewise regression analysis of the spring (16 April - 15 May) temperature in Troms, however, shows a corresponding break in 1995 with no prior increase $(\mathrm{p}=0.63)$ and a significant increase during the last 20 years $\left(r^{2}=0.24, d f=20, p=0.022\right)$. Whereas the earlier study showed a similar break in arrival dates of Pied Flycatchers with an advance after 1999 (Barrett 2011), the addition of six years of data resulted in the advance to become continuous between 1980 and 2016.

Elsewhere in Europe, there is strong evidence of an advance in migration of all three species. Willow Warblers and Chiffchaffs have advanced passage times through Helgoland in the SE North Sea in the period 1960-2000 at rates of 0.23 and $0.13 \mathrm{~d} \mathrm{yr}^{-1}$ respectively (Hüppop \& Hüppop 2003) and arrivals in Britain between 1963 and 2010 at rates of ca. 0.2 and $0.3 \mathrm{~d} \mathrm{yr}^{-1}$ respectively (Newson et al. 2016). Similarly, at least one aspect of arrival distribution (first, mean or median arrival date) at locations in England, Germany, Finland and Russia advanced significantly during the last half of the 20th century (Sparks et al. 2005) whereas the same tendencies (but statistically insignificant trends) were found for both species arriving in W. Poland in 19832003 (Tryjanowski et al. 2005). Willow Warblers also advanced their first arrival dates in southern Sweden in 1989-2012 by $0.2 \mathrm{~d} \mathrm{yr}^{-1}$ (Hedlund et al. 2014).

The arrival dates of Pied Flycatchers, on the other hand, seem to be less flexible. While dates of passage through Helgoland (Hüppop \& Winkel 2006) and arrival dates of early migrants in SW Finland (19702002, Ahola et al. 2004) and at two Lithuanian Baltic Sea sites (Rybachy [1959-2002] and Jurmo [19701999], Sparks et al. 2005) and in North Norway (this study) have advanced, arrival dates of first arrivals at five breeding sites in Germany did not change during the last four decades of the 20th century (Hüppop \& Winkel 2006). Nor did they change at a site in the Netherlands between 1980 and 2000, a period during which temperatures rose and laying dates advanced (Both \& Visser 2001).

Chiffchaffs arrived in Troms 10 d earlier thanWillow
Warblers but further east, in the Lower $\mathrm{Ob}^{\text {' region in }}$ Russia (at approx. $66^{\circ} \mathrm{N}$ ), Chiffchaffs arrived a month later than in Troms and six days later than Willow Warblers (Ryzhanovskii 2008).

Local environmental conditions in African wintering areas have been shown to influence arrival times of several trans-Saharan migrants in more southern breeding areas, e.g. Iberia (Gordo et al. 2005), Italy (Saino et al. 2007) and England (Cotton 2003). Furthermore, much of the variation in arrival dates of five of six trans-Saharen migrants in NE Spain and nine in Italy could be explained by monthly temperature and precipitation patterns in the African wintering areas (Gordo et al. 2005, Saino et al. 2007). In Africa, rain may improve feeding conditions enabling birds to reach optimal body condition at an earlier date and bring forward the onset of migration. Lack of rain resulting in poorer conditions may thus delay departure (Both 2010) although it can be argued that it may induce migrants to depart early and thus avoid food shortage (Sokolov \& Kosarev 2003). An alternative response to improved winter conditions may be to optimize the chance of safely passing the Sahara Desert by delaying departure (Tøttrup et al. 2008). At the individual level, variation in arrival times of Pied Flycatchers at the breeding site in Holland in 2014 was shown to be caused by variation in departure date ca 2 weeks previously, and not by environmental conditions encountered en route (Ouwehand \& Both 2017). In this study, it seemed that Pied Flycatchers migrating to North Norway delayed their departure after a wet and cooler April.

Although the date of departure and factors affecting it may be important for at least some populations, conditions at stop-over sites on the way northwards may also influence the extent of resting and refuelling (e.g. Huin \& Sparks 1998, Gordo 2007, Tøttrup et al. 2008). High NAO indices, temperatures or vegetation development favour ecological conditions and hence food availability across Europe and have been shown to be strongly correlated to the arrival of many migrants to the SE North Sea and the Baltic Sea (Hüppop \& Hüppop 2003, Sokolov \& Kosarev 2003), Norway (Forchhammer et al. 2002) or northern Finland (Tøttrup et al. 2008). Similarly, environmental conditions (temperatures, rainfall or vegetation indices) along the migration route have been shown to influence arrival times of trans-Saharan migrants in Italy (Saino et al. 2007) and Pied Flycatchers breeding in SW Finland (Ahola et al. 2004) or Germany (Hüppop \& Winkel 2006) with birds moving faster in warmer weather. In this study such effects did not kick in until the birds approached the end of their migration and again demonstrates that changes in migration time and responses to the environment are not, and should not be considered homogenous (Sparks et al. 2005). From Italy to North Norway is a further $3000 \mathrm{~km}$ "as a crow flies", or from SW Finland a further $1000 \mathrm{~km}$. 
It is thus intuitive to believe that very long-distance migrants flying from central Africa are unable to assess conditions in North Norway on departure and that their arrival times will be independent of conditions during the initiation and early stages of movement. Although the departure time of Pied Flycatchers flying to North Norway may have been climate-related, they did not seem to respond to climate along the whole migration route, thus corroborating Gordo's (2007) hypothesis that, having flown for weeks through Europe, arrival dates in North Norway will be most strongly driven by weather and climatic fluctuations occurring towards the end of their travel. Departure of North Norwegian birds from the wintering areas in Africa thus seem to be partly under the influence of endogenous rhythms or photoperiodic stimuli (Gwinner 1996) and their travel northwards is independent of environmental conditions until they approach their goal. At high north latitudes, weather in spring is very changeable (pers. obs.) such that it is critical that birds do not to arrive too early and face possible adverse weather and food shortage (Newton 2007), but at the same time, they should arrive as early as possible to gain the best nesting sites and mates and to increase chances of extra clutches (Gordo 2007 and refs. therein). Adjustments of the final arrival date can only be optimised in response to conditions near the end of their journey.

Acknowledgements. This study was funded by Tromsø University Museum. Thanks also to members of the local branch of the Norwegian Ornithological Society and members of the public who reported arrival dates to me or to www.artsobservasjoner.no. Without them this study would have been impossible.

\section{REFERENCES}

Ahola, M., Laaksonen, T., Sippola, K., Eeva, T., Rainio, K. \& Lehikoinen, E. 2004. Variation in climate warming along the migration route uncouples arrival and breeding dates. Global Change Biology 10: 1610-1617.

Bakken, V., Runde, O. \& Tjorve, E. 2006. Norsk Ringmerkingsatlas. Vol. 2. Stavanger Museum, Stavanger. $446 \mathrm{pp}$.

Barrett, R.T. 2002. The phenology of spring migration to North Norway. Bird Study 49: 270-277.

Barrett, R.T. 2011. Recent response to climate change among migrant birds in northern Norway. Ringing and Migration 26: 83-93.

Both, C. 2010. Flexibility of timing of avian migration to climate change masked by environmental constraints en route. Current Biology 20: 243-248.

Both, C. \& Visser, M.E. 2001. Adjustment to climate is constrained by arrival date in a long-distance migrant bird. Nature 411: 296-298.

Catry, P., Lecoq, M., Araújo, A., Conway, G., Felgueiras, M., King, J.M.B., Rumsey, S., Salima, H. \& Tenreiro, P.
2005. Differential migration of chiffchaffs Phylloscopus collybita and P. ibericus in Europe and Africa. Journal of Avian Biology 36: 184-190.

Cotton, P.A. 2003. Avian migration phenology and global climate change. Proceedings of the National Academy of Sciences of the United States of America 100: 12219-12222.

Forchhammer, M.C., Post, E. \& Stenseth, N.C. 2002. North Atlantic Oscillation timing of long- and short-distance migration. Journal of Animal Ecology 71: 1002-1014.

Gordo, O. 2007. Why are bird migration dates shifting? A review of weather and climate effects on avian migratory phenology. Climate Research 35: 37-58.

Gordo, O., Brotons, L., Ferrer, X. \& Comas, P. 2005. Do changes in climate patterns in wintering areas affect the timing of the spring arrival of trans-Saharan migrant birds? Global Change Biology 11: 12-21.

Gwinner, E. 1996. Circannual clocks in avian reproduction and migration. Ibis 138: 47-63.

Hedenström, A. \& Pettersson, J. 1987. Migration routes and wintering areas of Willow Warblers Phylloscopus trochilus (L.) ringed in Fennoscandia. Ornis Fennica 64: 137-143.

Hedlund, J.S.U., Jakobsson, S., Kullberg, C. \& Fransson, T. 2014. Long-term phenological shifts and intra-specific differences in migratory change in the Willow Warbler Phylloscopus trochilus. Journal of Avian Biology 46: 97-106.

Huin, N. \& Sparks, T.H. 1998. Arrival and progression of the Swallow Hirundo rustica through Britain. Bird Study 45: 361-370.

Hüppop, O. \& Hüppop, K. 2003. North Atlantic Oscillation and the timing of spring migration in birds. Proceedings of the Royal Society of London, B 270: 233-240.

Hüppop, O. \& Winkel, W. 2006. Climate change and timing of spring migration in the long-distance migrant Ficedula hypoleuca in central Europe: the role of spatially different temperature changes along migration routes. Journal of Ornithology 147: 344-353.

Jenouvrier, S. 2013. Impacts of climate change on avian populations. Global Change Biology 19: 2036-2057.

Lehikoinen, E. \& Sparks, T.H. 2010. Changes in migration. Pp. 89-112 in Møller, A.P., Fiedler, W. \& Berthold, P. (eds.) Effect of Climate Change on Birds. Oxford University Press, Oxford.

Lehikoinen, E., Sparks, T.H. \& Zalacevicius, M. 2006. Arrival and departure dates. Advances in Ecological Research 35: 1-31.

Marra, P.P., Francis, C.M., Mulvihill, R.S. \& Moore, F.R. 2005. The influence of climate on the timing and rate of spring bird migration. Global Change Biology 142: 307-315.

Newson, S.E., Moran, N.J., Musgrove, A.J., Pearce-Higgins, J.W., Gillings, S., Atkinson, P.W., Miller, R., Grantham, M.J. \& Baillie, S.R. 2016. Long-term changes in the migration phenology of UK breeding birds detected by large-scale citizen science recording schemes. Ibis 158 : 
481-495.

Newton, I. 2007. Weather-related mass-mortality events in migrants. Ibis 149: 453-467.

Oewehand, J., Ahola, M.P., Ausems, A.N.M.A., Bridge, E.S., Burgess, M., Hahn, S., Hewson, C.M., Klaassen, R.H.G., Laaksonen, T., Lampe, H.M., Velmala, W. \& Both, C. 2016. Light-level geolocators reveal migratory connectivity in European populations of Pied Flycatchers Ficedula hypoleuca. Journal of Avian Biology 47: 69-83.

Ouwehand, J. \& Both, C. 2016. Alternate non-stop migration strategies of Pied Flycatchers to cross the Sahara desert. Biology Letters 12: 20151060. http://dx.doi. org/10.1098/rsbl.2015.1060.

Ouwehand, J. \& Both, C. 2017. African departure rather than migration speed determines variation in spring arrival in Pied Flycatchers. Journal of Animal Ecology 86: 88-97.

Ryan, S.E. \& Porth, L.S. 2007. A tutorial on the piecewise regression approach applied to bedload transport data. General Technical Report RMRS-GTR-189. Fort Collins, CO: U.S. Department of Agriculture, Forest Service, Rocky Mountain Research Station. 41 p.

Ryzhanovskii, V.N. 2008. Dates and duration of the basic seasonal phenomena in the annual cycle of passerines of the Subarctic Zone on the example of the Lower Ob' region. Contemporary Problems of Ecology 1:227-237.

Saino, N., Rubolini, D., Jonzén, N., Ergon, T., Montemaggiori, A., Stenseth, N.C. \& Spina, F. 2007. Temperature and rainfall anomalies in Africa predict timing of spring migration in trans-Saharan migratory birds. Climate Research 35: 123-134.
Sokolov, L.V. \& Kosarev, V.V. 2003. Relationship between timing of arrival of passerines to the Courish Spit and North Atlantic Oscillation index (NAOI) and precipitaion in Africa. Proceedings of the Zoological Institute of the Russian Academy of Sciences 299: 141-154.

Sparks, T.H., Bairlein, F., Bojarinova, J.G., Hüppop, O., Lehikoinen, E.A., Rainio, K., Sokolov, L.V. \& Walker, D. 2005. Examining the total arrival distribution of migratory birds. Global Change Biology 11: 22-30.

Sparks, T.H., Roberts, D.R. \& Crick, H.Q.P. 2001. What is the value of first arrival dates of spring migrants in phenology? Avian Ecology and Behaviour. 7: 75-85.

Thingstad, P.G., Hogstad, O. \& Speed, J.D.M. 2015. The influence of climatic conditions in breeding grounds and migratory flyways on a subalpine Norwegian Willow Warbler (Phylloscopus trochilus) population. Ornis Fennica 92: 23-33.

Tryjanowski, P., Kuźniak, S. \& Sparks, T.H. 2005. What affects the magnitude of change in first arrival dates of migrant birds? Journal of Ornithology 146: 200-205.

Tøttrup, A.P., Thorup, K., Rainio, K., Yosef, R., Lehikoinen, E. \& Rahbek, C. 2008. Avian migrants adjust migration in response to environmental conditions en route. Biology Letters 4: 685-688.

Usui, T., Butchart, S.H.M. \& Phillimore, A.B. 2017. Temporal shifts and temperature sensitivity of avian spring migratory phenology: a phylogenetic meta-analysis. Journal of Animal Ecology 86: 250-261.

Received 16 March 2017. Accepted 18 April 2017 
Appendix 1. Overview of the proxies used in the regression models examining the variation in arrival dates of migrants to Troms, North Norway. Sources: JISAO (Joint Institute for the Study of the Atmosphere and Ocean, Univ. of Washington, http://research. jisao.washington.edu/data/sahel/), NOAA (National Centers for Environmental Information, Climate at a Glance: Global mapping, https://www.ncdc.noaa.gov/cag/mapping/global), NCAR (National Center for Atmospheric Research, National Science Foundation, https://climatedataguide.ucar.edu/climate-data/hurrell-north-atlantic-oscillation-nao-index-pc-based), IRI (International Research Institute for Research and Climate, Columbia University, http://iridl.ldeo.columbia.edu) and NMI (Norwegian Meteorological Institute, www.eklima.no)

\begin{tabular}{lllll}
\hline Proxy for & Region & Area & Time period & Source \\
\hline 1. Winter habitat quality & Sahel PA & $10^{\circ}-20^{\circ} \mathrm{N}, 20^{\circ} \mathrm{W}-10^{\circ} \mathrm{E}$ & June-October in yr-1 & JISAO \\
2. Departure conditions & Sahel PA & $10^{\circ}-20^{\circ} \mathrm{N}$ and $20^{\circ} \mathrm{W}-10^{\circ} \mathrm{E}$ & March \& April & JISAO \\
3. Departure conditions & W. Africa TA & $0^{\circ}-15^{\circ} \mathrm{N}, 15^{\circ} \mathrm{W}-10^{\circ} \mathrm{E}$ & March \& April & NOAA \\
3. Departure conditions & W. Africa TA & $0^{\circ}-15^{\circ} \mathrm{N}, 10^{\circ}-25^{\circ} \mathrm{E}$ & March \& April & NOAA \\
4. Departure and en route conditions & NAO index & N Atlantic & Dec-March & NCAR \\
5. En route conditions & France TA & $45^{\circ}-50^{\circ} \mathrm{N}, 0^{\circ}-10^{\circ} \mathrm{E}$ & April & NOAA \\
5. En route conditions & N Balkans TA & $45^{\circ}-50^{\circ} \mathrm{N}, 10^{\circ}-25^{\circ} \mathrm{E}$ & April & NOAA \\
5. En route conditions & S Sweden temps. $45^{\circ}-50^{\circ} \mathrm{N}, 10^{\circ}-25^{\circ} \mathrm{E}$ & April \& May & IRI \\
5. En route conditions & N Sweden temps. $66^{\circ}-68^{\circ} \mathrm{N}, 20^{\circ}-22^{\circ} \mathrm{E}$ & April \& May & IRI \\
6. Arrival conditions & Tromsø temps. Tromsø Met. Stn. & 16 April-15 May & NMI \\
\hline
\end{tabular}

1. The precipitation anomaly (PA, based on the 1901-2016 mean) in the Sahel in June-October in the preceding year. Positive index values indicate a higher precipitation than the long-term mean, and negative a lower precipitation.

2. Mean of the monthly Sahel precipitation anomaly (PA) indices for March and April.

3. Mean March-April temperature anomalies (TA, based on the 1981-2010 mean) in W. Africa and E. Africa, respectively (Fig. 1).

3. Winter (December-March) North Atlantic Oscillation Index (PC-based).

5. Mean monthly temperature anomalies in France and in the northern Balkans in April and absolute temperature measurements in S. and N. Sweden (mean of April \& May).

6. Annual means of daily mean temperatures between 16 April and 15 May recorded at Tromsø Meteorological Station. 
Appendix 2. Temperature time series in the wintering area (W. and E. Africa, mean of March \& April) for Willow Warblers and Pied Flycatchers and en route (France and N. Balkans in April and S. and N. Sweden in April/May) to their breeding area in North Norway (Tromsø, mid-April to mid-May; see methods). All trend lines except that for N. Sweden are significant $(\mathrm{p} \leq 0.01)$.
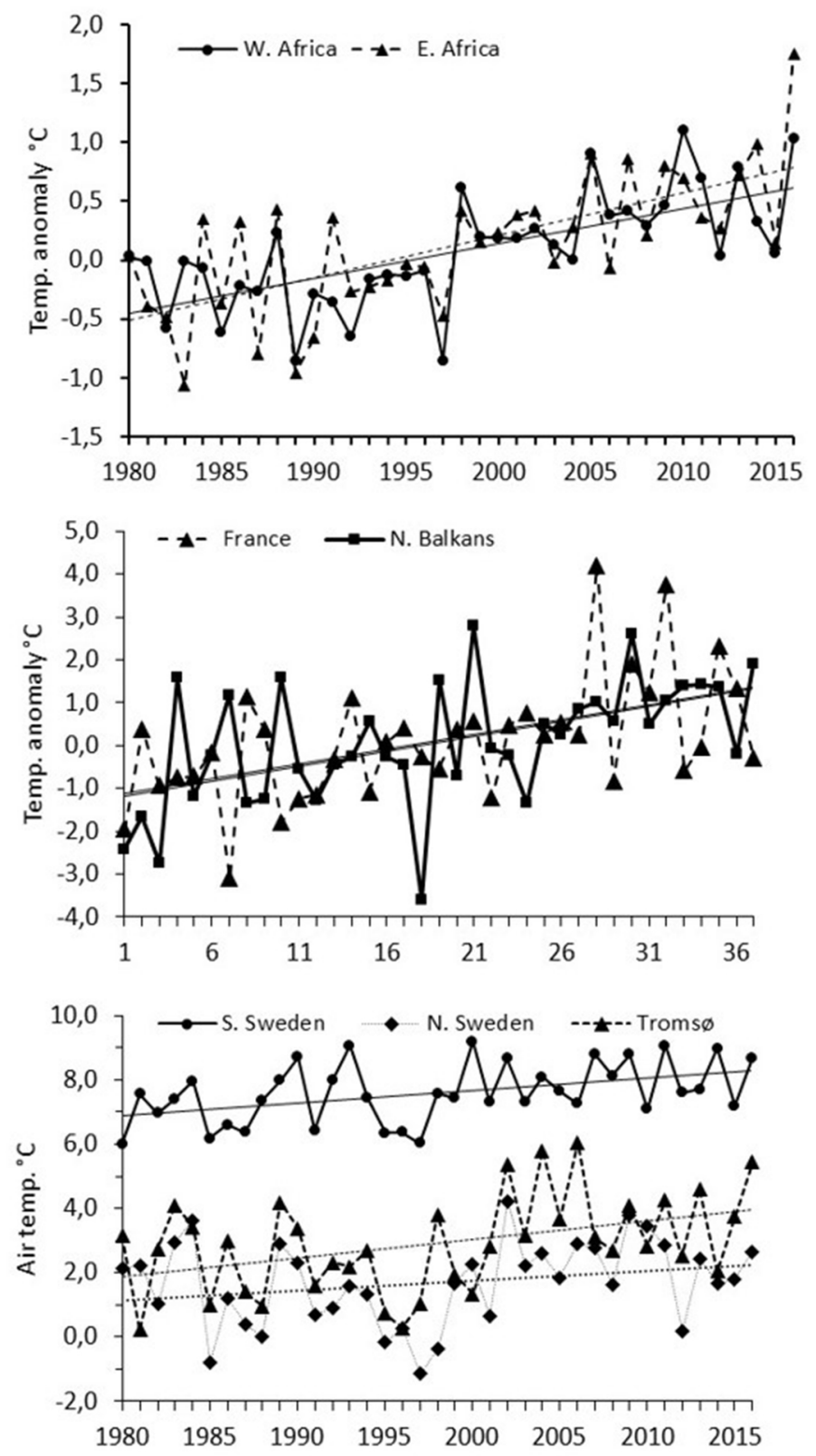
Appendix 3. Observed dates of arrival (2nd and 3rd observations) of spring-migrating Chiffchaffs, Willow Warblers and Pied Flycatchers at Troms, North Norway in 1980-2016. - = insufficient data (see Methods).

\begin{tabular}{|c|c|c|c|c|c|}
\hline & \multicolumn{2}{|c|}{ Chiffchaff } & $\begin{array}{l}\text { Willow Warbler } \\
2^{\text {nd }} \text { obs. } 3^{\text {rd }} \text { obs. }\end{array}$ & \multicolumn{2}{|c|}{$\begin{array}{l}\text { Pied Flycatcher } \\
2^{\text {nd }} \text { obs. } 3^{\text {rd }} \text { obs. }\end{array}$} \\
\hline 1980 & - & - & 17 May 26 May & 15 May & 15 May \\
\hline 1981 & - & - & 15 May 18 May & 12 May & 15 May \\
\hline 1982 & - & - & 21 May 22 May & 16 May & 17 May \\
\hline 1983 & - & - & 11 May 13 May & 7 May & 10 May \\
\hline 1984 & 8 May & 8 May & 17 May 19 May & 15 May & 15 May \\
\hline 1985 & 3 May & 5 May & 15 May 19 May & 10 May & 11 May \\
\hline 1986 & 2 May & 4 May & 9 May 10 May & 9 May & 9 May \\
\hline 1987 & 6 May & 6 May & 18 May 21 May & 5 May & 5 May \\
\hline 1988 & 5 May & 7 May & 12 May 14 May & 6 May & 10 May \\
\hline 1989 & 17 Apr & $18 \mathrm{Apr}$ & 17 May 17 May & 3 May & 12 May \\
\hline 1990 & $22 \mathrm{Apr}$ & $23 \mathrm{Apr}$ & 12 May 15 May & 11 May & 14 May \\
\hline 1991 & $28 \mathrm{Apr}$ & $29 \mathrm{Apr}$ & 18 May 20 May & 15 May & 16 May \\
\hline 1992 & 6 May & 10 May & 21 May 22 May & 10 May & 10 May \\
\hline 1993 & 1 May & 1 May & 2 May 2 May & 2 May & 2 May \\
\hline 1994 & 3 May & 3 May & 12 May 20 May & 5 May & 6 May \\
\hline 1995 & 11 May & 11 May & 21 May 21 May & 13 May & 15 May \\
\hline 1996 & 9 May & 12 May & 21 May 22 May & 5 May & 11 May \\
\hline 1997 & 6 May & 6 May & 19 May 21 May & 14 May & 14 May \\
\hline 1998 & $25 \mathrm{Apr}$ & $25 \mathrm{Apr}$ & 8 May 18 May & 7 May & 8 May \\
\hline 1999 & $25 \mathrm{Apr}$ & $27 \mathrm{Apr}$ & 20 May 21 May & 18 May & 18 May \\
\hline 2000 & $30 \mathrm{Apr}$ & 3 May & 17 May 18 May & 13 May & 13 May \\
\hline 2001 & 29 Apr & $30 \mathrm{Apr}$ & 13 May 17 May & 10 May & 11 May \\
\hline 2002 & $28 \mathrm{Apr}$ & $28 \mathrm{Apr}$ & 2 May 3 May & 4 May & 6 May \\
\hline 2003 & $21 \mathrm{Apr}$ & $22 \mathrm{Apr}$ & 7 May 9 May & 8 May & 9 May \\
\hline 2004 & 17 Apr & $18 \mathrm{Apr}$ & $28 \mathrm{Apr} 30 \mathrm{Apr}$ & 3 May & 3 May \\
\hline 2005 & $17 \mathrm{Apr}$ & $18 \mathrm{Apr}$ & 12 May 16 May & $30 \mathrm{Apr}$ & $30 \mathrm{Apr}$ \\
\hline 2006 & $23 \mathrm{Apr}$ & $23 \mathrm{Apr}$ & 2 May 8 May & 3 May & 5 May \\
\hline 2007 & $22 \mathrm{Apr}$ & $25 \mathrm{Apr}$ & 6 May 8 May & 7 May & 8 May \\
\hline 2008 & $28 \mathrm{Apr}$ & $28 \mathrm{Apr}$ & 2 May 2 May & 1 May & 2 May \\
\hline 2009 & $22 \mathrm{Apr}$ & $22 \mathrm{Apr}$ & 2 May 4 May & 3 May & 4 May \\
\hline 2010 & $11 \mathrm{Apr}$ & $20 \mathrm{Apr}$ & 6 May 7 May & 6 May & 8 May \\
\hline 2011 & 22 Apr & $22 \mathrm{Apr}$ & 9 May 10 May & 2 May & 4 May \\
\hline 2012 & $24 \mathrm{Apr}$ & $24 \mathrm{Apr}$ & 15 May 16 May & 5 May & 7 May \\
\hline 2013 & $21 \mathrm{Apr}$ & $22 \mathrm{Apr}$ & 15 May 16 May & 3 May & 4 May \\
\hline 2014 & $24 \mathrm{Apr}$ & $24 \mathrm{Apr}$ & 7 May 8 May & 5 May & 9 May \\
\hline 2015 & 27 Apr & $30 \mathrm{Apr}$ & 1 May 10 May & 3 May & 3 May \\
\hline 2016 & $16 \mathrm{Apr}$ & $18 \mathrm{Apr}$ & 2 May 2 May & 4 May & 5 May \\
\hline
\end{tabular}

